\title{
From Counting of E. coli to Pathogen Detection by Molecular Methods
}

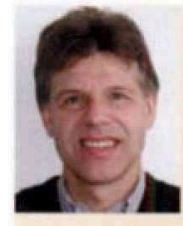

Thomas Egli and Wolfgang Köster

Swiss Federal Institute for Environmental

Science and Technology (EAWAG)

CH-8600 Dübendorf (Switzerland)

E-Mail: egli@eawag.ch

http://www.eawag.ch

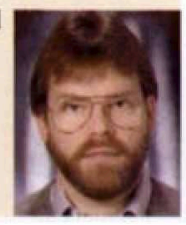

hroughout the 19 th century most of the big cities in the
world repeatedly suffered from severe epidemics of cholera
and typhoid fever, which claimed thousands of deaths. In
Hamburg, for example, the cholera epidemic of 1892 affected
more than 17000 people and 8500 died, corresponding to
13 percent of the total population. John Snow, the prominent
epidemiologist who studied cholera outbreaks in England
around 1850 , suspected that this disease was spread by drink-
ing water from wells contaminated with sewage or night soil
(dry excreta). He postulated that some "morbid material" in
faeces from cholera-infected persons could contaminate
drinking water and spread in this way [1'. By removing the

Table 1. Disease transmission and indicator concept: The early years.

Before 1800 Diseases thought to be transmitted via air; protection from "bad odours".

1850-1900 Obtaining proof that cholera and typhoid is caused by microbes and is transmitted via drinking water.

1854 Cholera epidemics in London; J. Snow removes Broad Street pump handle.

1873 W. Budd: Typhoid is transferred via drinking water.

1880 C.J. Eberth: Salmonella typhi causes typhoid.

1884 G. Gaffky isolates Salmonella typhi in pure culture /

$R$. Koch isolates Vibrio cholerae.

1892 Cholera epidemics in Hamburg.

1885 T. Escherich isolates "Bacillus coli commune" (Escherichia coli) from faeces.

1892 F. Schardinger proposes the use of $E$. coli as an indicator for faecal contamination of water (indicator concept).

1893-1894 R. Koch / P. Frankland: The number of heterotrophic microbes in water is a measure of pollution. In sea and freshwater it should be $<100 / \mathrm{ml}$. Slow sand filtration removes microbes from river water to $<100 / \mathrm{ml}$.

Table 2. The indicator concept: requirements for an indicator organism.

Indicator

- should be present when a source of pathogenic microorganisms; is present and should be absent in unpolluted water;

- should not multiply in the environment;

- should be present in higher number than the pathogens;

- should behave in the environment and in water treatment

processes in a similar way as pathogens;

- should be easy to isolate, identify and enumerate.

and preferably also:

enumeration and detection method should be inexpensive;

indicator should itself not be pathogenic to minimise

risks to analysts. pump handle in London's Broad Street from the well that he suspected to be contaminated he was able to stop the cholera epidemic. It took some 30 to 40 years before microbes originating from faeces of ill persons and spreading via water were clearly shown to be the cause of epidemics such as cholera and typhoid fever (Table 1). Only at the end of the 19th century the most important pathogenic microorganisms causing waterborne disease, Vibrio cholerae and Salmonella typhi, were isolated and studied in pure culture ${ }^{[2,3]}$.

\section{The indicator concept}

In 1885 Theodor Escherich isolated from faeces of new-born and suckling babies a motile, milk-clotting (lactose-utilising, acid producing) rod he referred to as Bacterium coli commune (now Escherichia coli) and a number of other E. coli-like bacteria, the so-called coliforms ${ }^{[4]}$. He and others observed that this bacterium established in the infant colon within a few weeks after birth. Since this bacterium was invariably found to be a characteristic component of the faecal flora, Schardinger ${ }^{[5]}$ proposed that the detection of coliforms in water could be taken as "an indication of faecal pollution and therefore of the potential presence of enteric pathogens" (Table 2). Only a few years later members of the group of coliform bacteria were found to inhabit also unpolluted water and soil. Hence, their presence in a water sample could not exclusively be taken as an indication for its pollution with faecal matter. An improved method for the detection of specifically faeces-related coliforms was introduced already in $1904^{[6]}$, namely by enumeration of the so-called thermotolerant (or faecal) coliforms at an increased temperature of $46^{\circ} \mathrm{C}$ (now $44-45^{\circ} \mathrm{C}$ ), in contrast to the $37^{\circ} \mathrm{C}$ used before. Eventually, it was shown that among the group of thermotolerant coliforms the very Escherichia coli should preferably be used as faecal pollution indicator organism. It is the only member of this group that is invariably present and always outnumbers other thermotolerant coliforms in excreta of warmblooded animals ${ }^{[7]}$. Despite the fact that the use of (thermotolerant) coliforms and/or $E$. coli as microbial parameters for testing drinking water quality has several drawbacks (discussed below), this method is most commonly applied, not least because of the simplicity and low costs of the detection and enumeration methods. The indicator concept based on $E$. coli has been in use for decades and has definitely helped to improve the safety of drinking water. It has been adopted in the World Health Organization (WHO) drinking water quality guidelines ${ }^{[8]}$ and is used in all national quality standards. As supporting hygienic parameters, total heterotrophic aerobic mesophilic microbes and faeces-derived enterococci are often detected to assess the biological quality of drinking water. However, they have never gained the widespread acceptance of coliform- or E. coli-testing ${ }^{[9]}$.

\section{Failure of the $E$. coli-based indicator concept}

The role of indicator microbes (bacteria) was originally that of an indicator of faecal pollution and consequently of a likely health risk. Later, application of coliform-testing and 
the indicator concept were extended and they were employed also to monitor the efficiency of drinking water production processes and post-treatment contamination.

However, faecal-oral diseases spread via drinking water are not only caused by bacteria but also by viruses or protozoa, and the latter two groups behave quite differently with respect to their survival characteristics in the environment and during water treatment processes. This is particularly true for the disinfection of drinking water where $E$. coli is very sensitive, whereas some viruses and parasites can be extremely resistant. Hence, the initial interpretation, namely that the concentration of indicator organisms would reflect the extent of faecal contamination (implicitly also the potential concentration of pathogens), and, hence, the incidence of water-borne disease, was never strictly valid ${ }^{[10,11]}$. Despite this, $E$. coli and (thermotolerant) coliforms are still used widely as the (often only) method to assess the microbial quality of drinking water.

The use of (thermotolerant) coliforms, $E$. coli or enterococci as indicators of faecal pollution was certainly successful in protecting consumers from water-borne cholera and typhoid. However, over the last three decades a number of outbreaks of viral and protozoan illnesses have occurred that were associated with drinking water meeting the coliform standards, confirming that coliforms are not always the right parameter to assess the biological standard of drinking water. The most prominent case is probably that of the Cryptosporidium

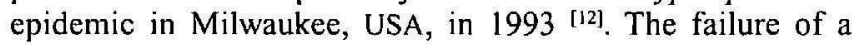
filter unit led to a break-through of Cryptosporidium oocysts. After filtration the water was disinfected by chlorination before distribution and from the subsequent coliform testing there was no indication that the water quality was compromised. But this was obviously not sufficient because the oocysts from this protozoan pathogen are very resistant towards chlorine disinfection. The number of people affected was estimated to be in the range of $400000^{\text {[12]. Numerous }}$ similar outbreaks of intestinal illness due to contamination of drinking water with viruses or protozoa associated with water meeting the coliform standards have been reported ${ }^{[9]}$.

Such events point out the major problems with respect to the protection of public health from microbial drinking water risks. First, the methods used for biological quality control rely mostly on testing for the presence of $E$. coli, but the absence of $E$. coli does not always ensure the absence of pathogens. The second major problem in terms of health protection is that monitoring biological safety of drinking water is always reactive. Testing for $E$. coli or thermotolerant coliforms takes at least 24 to 48 hours to obtain a result, and all other established test methods for detecting risk-indicating organisms (heterotrophs, enterococci, or pathogens directly) take even longer. Therefore, contamination with pathogens or failure of treatment is mostly detected by monitoring many hours or even days after it has occurred. An additional critical point of the present strategy is that it typically relies on monitoring the end-product only, whereas the microbial quality of the raw water and the efficiency of different treatment steps are usually not considered. Furthermore, the lack of available methods to reliably detect and quantify microbial pathogens is of great concern.

\section{Improved assessment of microbial safety of drinking water}

The problems encountered over the last two decades have led to a re-thinking of the needs and strategies to ensure the microbial safety of drinking water provided to the public. Recently, in a collaborative effort the OECD (Organisation for
Economic Co-operation and Development) and the WHO have presented a major review of the state of knowledge with respect to monitoring parameters and testing methods for assessing the microbial safety of drinking water. The overall conclusions reached and the recommendations given in the resulting Guidance Document ${ }^{[9]}$ can be summarised as follows: 1. The microbial risk of drinking water should be assessed at all stages between catchment and consumer and should not rely on end product monitoring only. "Multiple Barrier Concepts" and "Water Safety Plans" based on "Hazard Analysis at Critical Control Points" to prevent foreseeable harm at reasonable cost should be included.

2. One should not rely on a single parameter (coliforms) but select those biological parameters that are best suited to assess water quality at different stages, for example the efficiency of processes (barriers) during drinking water treatment and distribution. An overview of applicability and suitability of different microbial parameters for water quality control for individual steps from the catchment to the tap, as well as for outbreak investigations are listed in the Guidance Document.

3. The lack of available methods for a quick and reliable detection and quantification of indicators and water-borne pathogens is of great concern. New (molecular) methods should be investigated and developed that allow a faster assessment, ideally even on-line detection of microbial parameters.

\section{New molecular detection methods}

As indicated above, a major restriction in monitoring the microbiological quality of drinking water is the availability of sensitive, reliable and fast methods for the detection of indicator organisms or pathogens. Traditional methods rely on the cultivation of target organisms (for example $E$. coli) on selective growth media. Over the years these methods have been improved and standardised, for example by the International Organization for Standardization (ISO) or the European Committee for Standardization (CEN). Despite the progress made, most of the traditional methods are still time-consuming and frequently lack selectivity and specificity.

Over the last two decades a number of molecular methods based on biochemical, genetic or immunological principles have been developed, mainly for medical diagnostics. Many of these methods are now being introduced into drinking water analysis and adapted to the specific requirements. Although none of them has been standardised so far, they promise considerable advantages compared to traditional methods with respect to speed, sensitivity and selectivity for the detection and quantification of indicator organisms and pathogens in (drinking) water. In an OECD workshop the potential of new molecular methods for the detection of microbial indicator organisms and pathogens in drinking water was discussed ${ }^{[13]}$. For a detailed description of the different methods the reader is referred to the Guidance Document of the OECD/WHO ${ }^{[9]}$, where both the potential and the drawbacks of the respective methods are discussed.

It should be pointed out here that the analysis of drinking water is special in the way that very small numbers of indicator organisms or pathogens have to be detected. For example, in most countries drinking water must contain less than 1 cell of $E$. coli or of coliforms per $100 \mathrm{ml}$ of water to fulfil the legal requirement. This also applies to molecular techniques. Well-designed and quantitative concentration steps to harvest organisms or nucleic acids from large volumes of water samples are required for both traditional and molecular detection methods. 
The most frequently used molecular methods are based on the polymerase chain reaction (PCR), fluorescence in situ hybridisation (FISH), and immunological specificity. Below, the basic principles of these molecular techniques are explained shortly.

Detection of microbes and viruses based on PCR. After isolation of total nucleic acids from water samples, the PCR allows producing in vitro multiple copies of specific nucleic acid (Desoxyribonucleic acid, DNA) sequences present in the sample. Hence, not the whole organism or virus, but a particular stretch of its genetic material is searched for in a water sample and then amplified such that it becomes detectable. By selecting a DNA target sequence specific for a particular (sub)species, only this strain will be detected. Selecting DNA target sequences that are conserved in a specific group of organisms allows checking for the presence of all members of this group. Detection of specific pathogenic organisms can for example be achieved by targeting and amplifying DNA sequences coding for their virulence factors (cellular components that give an organism the ability to cause a certain disease in its host). The time needed for detection of an organism or a virus by PCR takes typically 3-4 hours. Including in the first step the enzyme reverse transcriptase (RT) - an enzyme able to transcribe RNA (Ribonucleic acid) target sequences into corresponding DNA sequences - followed by normal PCR allows also the detection of viruses containing RNA as their genetic material (for example the non-cultivatable Caliciviruses that cause different gastrointestinal water-borne diseases). RT-PCR is also used to obtain an indication whether or not particular microbes are viable in a sample by isolating and amplifying very short-lived mRNA (messenger RNA) species. This method has already been used to demonstrate the viability of various pathogens, including Legionella pneumophila, Vibrio cholerae or Cryptosporidium oocysts by checking for the presence of the heat-shock protein hsp70 mRNA.

PCR-based methods still have a number of drawbacks. First, isolation of nucleic acids from environmental samples may be difficult, not quantitative, and components present in the sample, for example humic acids, may inhibit the PCR. Second, it is not possible to distinguish whether the DNA sequence amplified stems from a living or a dead cell, or whether it was just a piece of free DNA from a lysed organism. Furthermore, quantification of the number of targets originally present in the sample is not possible with the basic PCR protocol and the certainty that a single target in a sample is detected is not given. Hence, the method still lacks robustness and reproducibility - goals towards which many laboratories are presently working - but has great potential for automation.

Detection of organisms based on fluorescence-labelled probes. Fluorescently labelled probes with high affinity to specific cellular components can be used to detect single organisms. For example, specific proteins or sugar moieties at the cell surface can be detected with labelled antibodies that bind specifically to such components. Marked cells can be visualised in a fluorescence microscope or detected in a flow-cytometer. However, direct visualisation by in situ hybridisation (that is, without previous PCR step) requires typically some 10000 target molecules that can be labelled in a cell. Similarly, the property of nucleic acids to hybridise and bind tightly to complementary sequences can be used for the detection of microbial indicators or pathogens. For example, intracellular nucleic acids present in high numbers in a cell, such as ribosomal RNA (rRNA) molecules, which are components of the protein synthesis apparatus and occur in active cells in about 30000 copies, can be visualised with fluorescently labelled rRNA probes. The method is today used routinely for the rapid detection and quantification of Cryptosporidium oocysts in (drinking) water in some countries ${ }^{[9]}$.

\section{Outlook}

The new molecular methods hold numerous combinations for the development of detection methods of both indicator organisms and pathogens. On the horizon are for example
Figure 1. For the analysis of drinking water samples DNA-chips offer the potential for fast and specific detection of the presence of DNA and/or RNA-molecules that occur specifically in pathogenic microbes or viruses.

\title{
The future: DNA-chips
}

Synthetic gene probes, e.g. for $E$. coli 16 S rRNA, pathogenicity factors, viral DNA or RNA

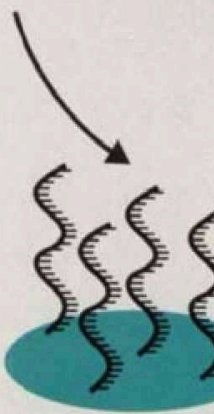

(n)

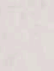


DNA microarray systems where different single-stranded probe DNAs (500-5000 bases long) are spotted on a solid glass surface, each spot with a sequence specific for a certain target organism. Hundreds or even thousands of different probe DNAs can be arranged by robot-spotting on an area of 1 square centimetre. These arrays are exposed to labelled target DNA isolated from environmental samples (usually after PCR amplification). Such "DNA chips" (Figure 1) would permit the detection of a range of targets simultaneously in one go within a few hours. However, most molecular techniques are not yet robust enough for routine daily use; also experience and an extensive database is lacking. They are therefore mainly employed at the research level. Hence, traditional $E$. coli-counting will remain the backbone for the assessment of biological safety of drinking water for some time.

\section{References}

[1] J. Snow: On the Mode of Communication of Cholera, John Churchill, London (1855).

[2] W. Budd: Typhoid Fever - Its Nature, Mode of Spreading and Prevention, Longmans, London (1873).

[3] R. Koch: "An address on cholera and its bacillus", British Medical Journal (August 30, 1884) 403-407 and 453-459.
[4] T. Escherich: "Die Darmbacterien des Neugeborenen und Säuglings", Fortschritte der Medicin 3 (1885) 515-527.

[5] F. Schardinger: "Über das Vorkommen Gährung erregender Spaltpilzc im Trinkwasser und ihre Bedeutung für die hygienische Beurtheilung desselben", Wiener Klinische Wochenschrift 5 (1892) 403-405.

[6] C. Eijkman: "Die Gärungsprobe bei $46^{\circ} \mathrm{C}$ als Hilfsmittel bei der Trinkwasseruntersuchung", Centralblatt für Bakteriologie Abtheilung I, 37 (1904) 742-752.

[7] A.P. Dufour: "Escherichia coli: the fecal coliform", in A.W. Hoadley, B.J. Dutka (Ed.): Bacterial Indicators/Health Hazards Associated with Water, ASTM, Philadelphia (1977), p. 48-58.

[8] WHO: Guidelines for Drinking Water Quality, Volume 3: Recommendations, $2^{\text {nd }}$ Edition, World Health Organization, Geneva (1997).

[9] OECD/WHO: Guidance Document - Assessing Microbial Safety of Drinking Waters - Perspectives for Improved Approaches and Methods, Organisation for Economic Co-operation and Development Paris / World Health Organization, Geneva (2003) in press.

[10] D.A.A. Mossel: "Index and indicator organisms: a current assessment of their usefulness and significance", Food Technology 30 (1978) 212-219.

[11] W.O. Pipes: "Indicators and water quality", in W.O. Pipes (Ed.): Bacterial Indicators of Pollution, CRC Press, Boca Raton (1982), p. 83-96.

[12] W.R. Mac Kenzie, N.J. Hoxie, M.E. Proctor, M.W. Gradus, K.A. Blair, D.E. Peterson, J.J. Kazmierczak, D.G. Addiss, K.R. Fox, J.B. Rose, J.P. Davis: "A massive outbreak in Milwaukee of Cryptospridium infection transmitted through public water supply", New England Journal of Medicine 33/ (1994) 161-167.

[13] Anonymous: Molecular Technologies for Safe Drinking Water The Interlaken Workshop, OECD, Paris (1999). For the proceedings see: http://www.eawag.ch/publications_e/proceedings/oecd.html.

\title{
Danyel Reiche
}

\section{Erneuerbare Energien in den Niederlanden}

\author{
Pfadabhängigkeiten, Akteure, Belief Systeme und Restriktionen \\ Mit einem Vorwort von Maarten Arentsen \\ Frankfurt/M., Berlin, Bern, Bruxelles, New York, Oxford, Wien, 2002. 134 S., zahlr. Abb., Tab. u. Graf. \\ ISBN 3-631-39911-1 · br. $€ 24.80$
}

Dieses Buch ist die erste umfassende deutschsprachige Veröffentlichung zur Situation erneuerbarer Energien in den Niederlanden. Nach einer Einführung in das politische System der Niederlande wird dargelegt, wie erneuerbare Energien in Holland definiert werden. Abschließend wird die Entwicklung sämtlicher, also auch nicht-erneuerbarer Energieträger in den Niederlanden eingehend beschrieben (Pfadabhängigkeiten), ehe die relevanten Akteure im Untersuchungsfeld präsentiert werden. Wie diese miteinander zusammenhängen, zeigt die folgende Analyse von Netzwerken und Belief Systemen. Daraufhin wird das Regulierungsmuster im Bereich erneuerbarer Energien vorgestellt. Der Schwerpunkt liegt dabei auf den gegenwärtig zum Einsatz kommenden Förderinstrumenten. Abschließend werden Restriktionen eines Transformationsprozesses in der holländischen Energiepolitik herausgearbeitet, um auf dieser Grundlage mögliche Erfolgsbedingungen identifizieren zu können.

Aus dem Inhalt: Einführung ins politisch-rechtliche System der Niederlande . Definition erneuerbarer Energie in Holland · Pfadabhängigkeiten in der niederländischen Energiepolitik · Akteure im Politikfeld erneuerbare Energien in den Niederlanden · Netzwerke und Belief Systeme - Regulierungsmuster - Restriktionen erneuerbarer Energien in den Niederlanden · Perspektiven und Erfolgsbedingungen

"Ich möchte dieses Buch deshaib empfehlen, weil es einem überzeugenden analytischen Gerüst folgt und einen konkreten Beitrag zur Politikberatung liefert, indem es aufzeigt, welche Restriktionen zu überwinden sind." (Maarten Arentsen) 